\author{
IULIANA GRAŻYŃSKA
}

Biblioteka Uniwersytecka w Poznaniu

\title{
Centralna Biblioteka Uniwersytecka Karola I w Bukareszcie ${ }^{1}$
}

Streszczenie. W artykule omówione zostały doświadczenia, jakie autorka zdobyła podczas stażu w ramach programu Erasmus w Centralnej Bibliotece Uniwersyteckiej Karola I w Bukareszcie, jednej z najbardziej dotkniętych przez los bibliotek. Autorka odnotowuje różnice i podobieństwa między rumuńskim i polskim systemem bibliotecznym, omawia metody opracowywania książek w Oddziale Zbiorów Specjalnych, pozostałe usługi biblioteczne oraz przypomina burzliwą historię biblioteki. Bukareszteńska Biblioteka Uniwersytecka pierwsza w Rumunii wprowadziła zintegrowany system informacji. Książki opracowuje się w programie komputerowym opisów bibliograficznych VUBIS, który używa formatu UNIMARC. Współpraca biblioteki z partnerami zagranicznymi pozwala na dostęp do najnowszych wyników badań i kompleksowych usług badawczych.

SŁowa KLuczowe: program Erasmus, Rumunia, Centralna Biblioteka Uniwersytecka Karola I w Bukareszcie, katalogowania zbiorów specjalnych.

W roku 2010 w ramach programu Erasmus odbyłam jednotygodniowy staż w Centralnej Bibliotece Uniwersyteckiej Karola I (Biblioteca Centrală Universitară) w Bukareszcie. Celem mojej wizyty było zaznajomienie się z metodami opracowania książek w Oddziale Zbiorów Specjalnych oraz pozostałymi usługami oferowanymi przez bibliotekę. Ponadto chciałam poznać najważniejsze kierunki w rumuńskim bibliotekoznawstwie. Moim gospodarzom w trakcie multimedialnej prezentacji opowiedziałam o powstaniu, rozwoju i współczesnych problemach Biblioteki Uniwersyteckiej w Poznaniu.

${ }^{1}$ Artykuł opiera się na informacjach otrzymanych w czasie stażu w Centralnej Bibliotece Uniwersyteckiej Karola I w Bukareszcie. Korzystałam także z następujących prac: Biblioteca Centrala Universitară din Bucureşti. O bibliografie a existenței 1891-2001, Bukareszt 2001 (Centralna Biblioteka Uniwersytecka w Bukareszcie. Bibliografia za lata 1891-2001); G. Costescu, Bucureştii vechiului regat, Bukareszt 2005 (Bukareszt królestwa rumuńskiego); Biblioteca Centrala Universitara "Carol I" (dokumenty online na stronie BCU, http://www.bcub.ro [dostęp: 22.05.2010]). 


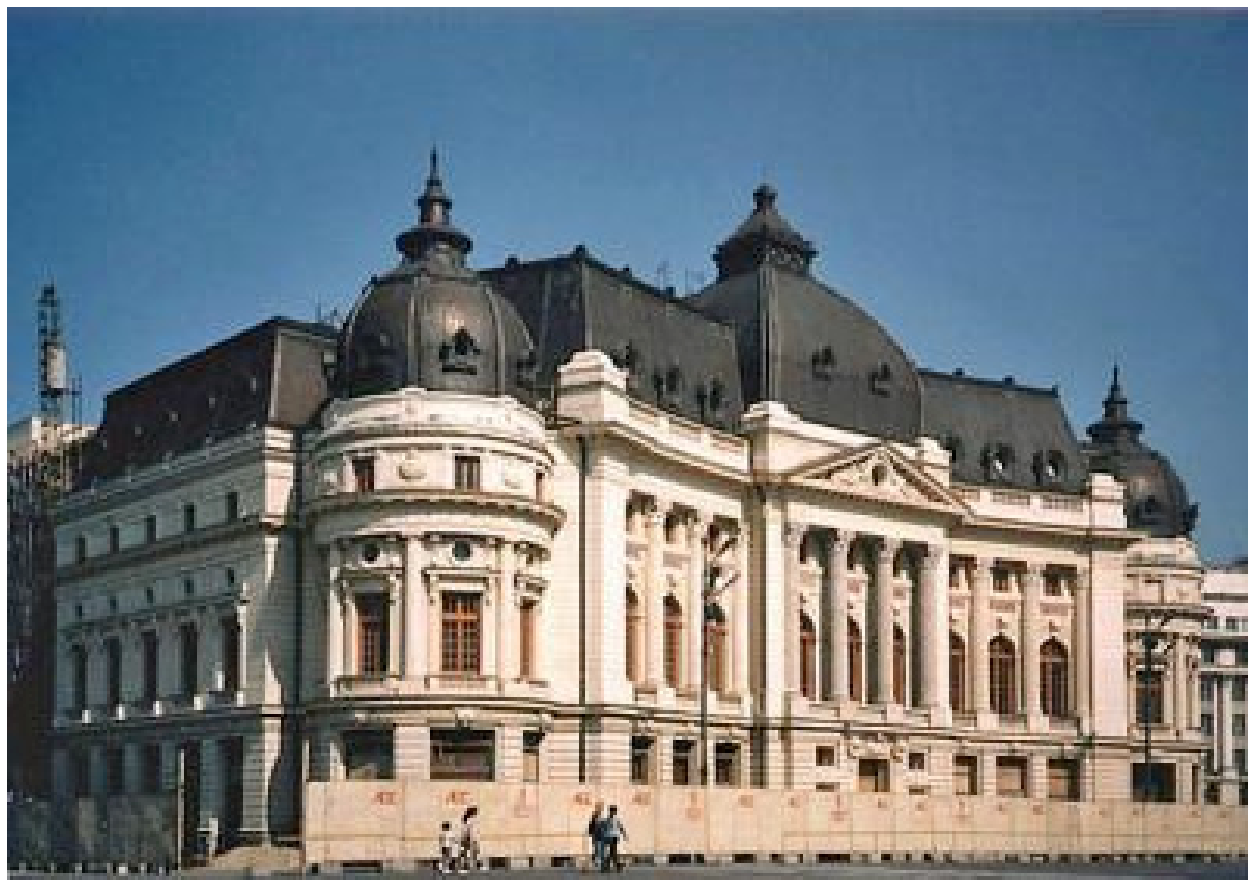

Il. 1. Centralna Biblioteka Uniwersytecka

Fot. Iuliana Grażyńska.

\section{Historia}

Bukareszteńską książnicę usytuowano w centrum stolicy, w sąsiedztwie innych historycznych budowli, takich jak Pałac Królewski (obecnie siedziba Muzeum Narodowego Sztuki Rumuńskiej) czy Ateneum Rumuńskie - siedziba Filharmonii Rumuńskiej, i wielu ministerstw (do 1990 roku znajdował się tu Komitet Centralny RPK).

Od założenia w roku 1895 aż do końca II wojny światowej Centralna Biblioteka Uniwersytecka Karola I była znana pod nazwą Biblioteka Fundacji Uniwersyteckiej lub Biblioteka Fundacji Karola I. Karol I Rumuński (1839-1914) chciał bowiem, aby powstała „biblioteka stale otwarta”, która wspierałaby młodzież m.in. przez przyznawanie stypendiów ułatwiających zdobycie wykształcenia. Królewskiemu życzeniu stało się zadość i 14 marca 1895 roku otwarto siedzibę fundacji, w której strukturze znalazła się również akademicka biblioteka. Przy tej okazji Karol I przypomniał słowa kronikarza rumuńskiego Mirona Costina (1633-1691): „bo nie ma innej piękniejszej i bardziej użytecznej zabawy w całym życiu ludzkim 
niż czytanie książek" ${ }^{2}$. Słowa Costina - notabene jednego z pierwszych pisarzy i historiografów tworzących w języku rumuńskim, który studiował w Polsce - nie straciły na aktualności do dziś.

Pierwszy zarząd nowej instytucji składał się z osób wiele znaczących $\mathrm{w}$ ówczesnym rumuńskim życiu kulturalnym, należeli do niego m.in.: Titu Maiorescu - rektor Uniwersytetu Bukareszteńskiego, Neculaie Culianu - rektor Uniwersytetu w Jassach i prawnik Ioan Kalinderu. Pierwszym dyrektorem fundacji został Gheorghe Dem Teodorescu profesor i były minister szkolnictwa. Po nim stanowisko to objął Alexandru Tzigara-Samurcas, historyk sztuki, członek korespondent Akademii Rumuńskiej.

W roku 1914 w związku z szybkim powiększaniem kolekcji, a także dzięki finansowemu wsparciu fundatora wybudowano dodatkowe skrzydło biblioteki. W nowym budynku znajdowało się najnowocześniejsze na owe czasy wyposażenie: metalowe regały na książki i pneumatyczne urządzenia do szybkiego wysyłania materiałów bibliotecznych do magazynów. Czytelnie urządzono na wzór Biblioteki Cesarskiej w Berlinie, a salę dla profesorów ozdobiono intarsjowanymi meblami, zamówionymi w tym celu w warsztatach angielskich. W wielu oknach pojawiły się witraże, sale oświetlały żyrandole i lampy wzorowane na tych, które znajdowały się w słynnym zamku Peleş w miejscowości Sinaia.

W roku 1944 budynek został poważnie uszkodzony podczas bombardowań prowadzonych przez lotnictwo amerykańskie. Szczególnie ucierpiały wówczas kopuła i ostatnie piętro. Gmach odrestaurowano ponownie po wielkim trzęsieniu ziemi w marcu 1977 roku. Habent sua fata libelli. Po raz kolejny doszło do dużych zniszczeń podczas rewolucji w grudniu 1989 roku, kiedy do biblioteki wjechały czołgi. Spłonęło wtedy 1500000 woluminów, w tym kolekcja bibliofilska obejmująca unikalne dokumenty, korespondencję, 12000 książek, ekslibrisy oraz 3700 rękopisów wielkich pisarzy rumuńskich, takich jak Mihai Eminescu, Mircea Eliade, Titu Maiorescu, Ion Luca Caragiale, Lucian Blaga i Mihail Sadoveanu. Wspominając rewoltę z grudnia 1989 roku (podczas prawdziwego auto da fé, na skutek czego siedziba biblioteki została zniszczona niemal w 80 procentach), nie sposób pominąć poświęcenia bibliotekarzy ratujących z popiołów to, co jeszcze można było ocalić. Dzięki ich ciężkiej pracy, zaangażowaniu i profesjonalizmowi odtworzono zbiory i odbudowano gmach biblioteki, który

${ }^{2}$ M. Costin, O mołdawskim narodzie, „Căci nu este alta, mai frumoasă şi mai de folos în toată viața omului zăbavă, decât cetitul cărtilor" 1686. Miron Kostyn opisuje historię Rumunii, od czasów Daków, przez kolonizację i podbój Dacji przez Rzymian, do powstawania księstw rumuńskich: Siedmiogrodu, Mołdawii i Wołoszczyzny. 


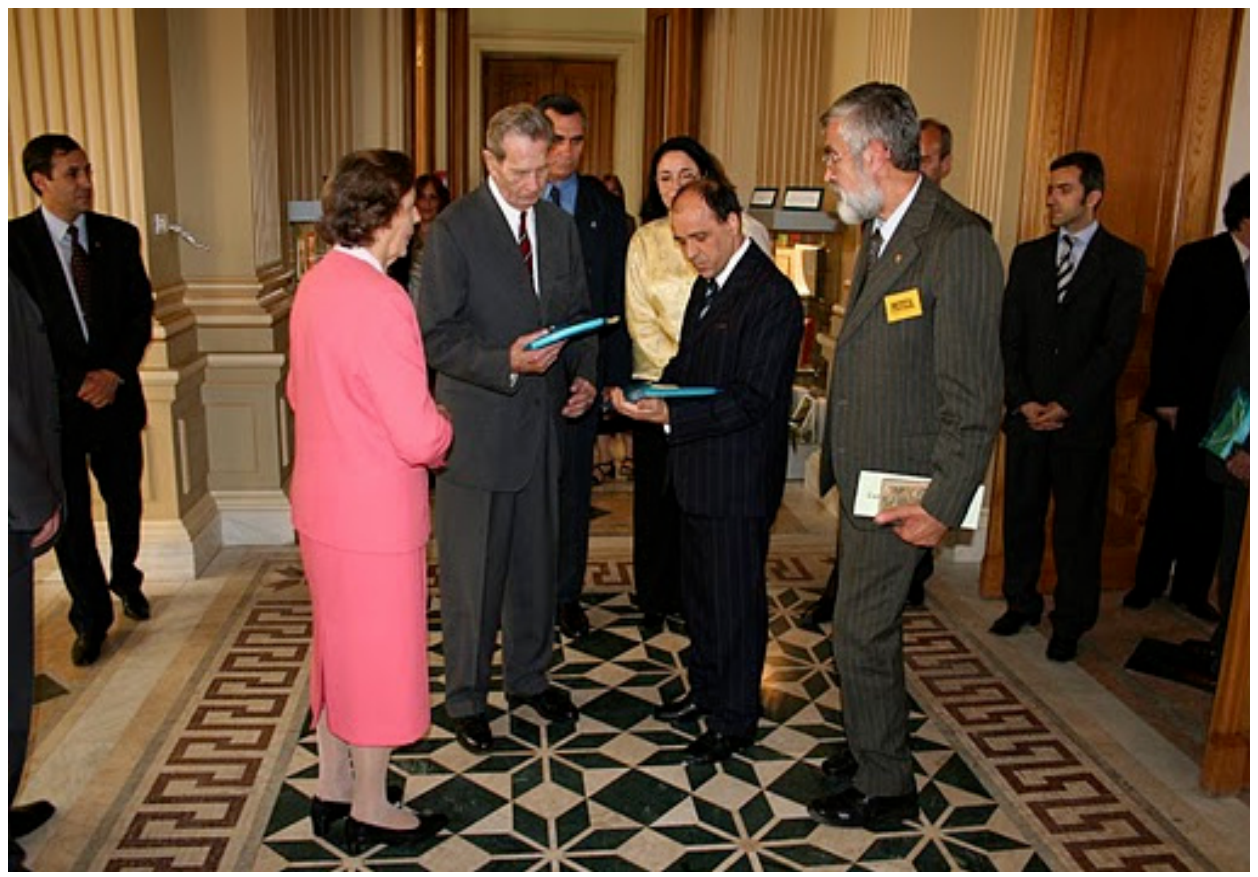

Il. 2. Wizyta rumuńskiej pary królewskiej w Centralnej Bibliotece Uniwersyteckiej, którą podejmują dyrektor prof. Mircea Regneala oraz kierownik Oddziału Zbiorów Specjalnych dr Doru Badara

Źródło: archiwum Centralnej Biblioteki Uniwersyteckiej Karola I w Bukareszcie.

dziś znów odzyskał dawną elegancję. Wysiłki bibliotekarzy wsparły zarówno osoby prywatne, jak i instytucje kulturalne kraju.

W Rumunii wciąż panuje kult czytelnictwa. Na ulicach Bukaresztu można zobaczyć wielu bukinistów oraz ludzi zakochanych w starych i rzadkich woluminach. To jeden z powodów, dla których władze Centralnej Biblioteki Uniwersyteckiej Karola I nie poprzestały na rekonstrukcji dawnych zbiorów. W roku 1990 przystąpiono do modernizacji i powiększenia budynku, dodano trzecie skrzydło, co zapewnia wejście do budynku biblioteki z trzech różnych ulic. W przygotowaniu projektu poświęconego informacji bibliotecznej pomocy finansowej udzieliło UNESCO.

Administracyjnie Centralna Biblioteka Uniwersytecka w Bukareszcie od 1948 roku jest instytucją z własną osobowością prawną i podlega bezpośrednio Ministerstwu Edukacji i Badań ${ }^{3}$ Na terenie stolicy koor-

${ }^{3} \mathrm{~W}$ Rumunii istnieją cztery centralne biblioteki uniwersyteckie $\mathrm{z}$ autonomiczną osobowością prawną: w Bukareszcie, w Iaşi, w Cluj-Napoca i w Timişoarze. Centralne biblioteki uniwersyteckie są bezpośrednio podporządkowane Ministerstwu 
dynuje pracę sieci informacyjno-bibliotecznej złożonej z 16 bibliotek zakładowych. Jej zasady gromadzenia są podporządkowane wymaganiom użytkowników, procesom dydaktycznym i badaniom naukowym.

\section{Struktura organizacyjna Centralnej Biblioteki Uniwersyteckiej w Bukareszcie}

W skład jednostki centralnej wchodzą następujące komórki organizacyjne:

- Oddział Ewidencji i Organizacji Kolekcji (Serviciul Evidenţă şi Organizarea Colecțiilor),

- Oddział Finansowy (Serviciul Financiar - Contabilitate),

- Oddział Referencji (Serviciul Referinţe) - współpraca Oddziału Informacji i Sekcji Wypożyczalnia,

- Oddział Katalogowania i Indeksowania (Serviciul Catalogare Indexare),

- Oddział Zbiorów Specjalnych (Biroul Bibliofilie, Manuscrise),

- Oddział Informatyzacji (Biroul de Informatizare),

- Oddział Rozwoju Kolekcji (gromadzenia) (Serviciul Dezvoltarea Colecțiilor),

- Oddział Czasopism (Serviciul Periodice),

- Oddział Badań Metodycznych, Zasobów Ludzkich i Rozwoju Zawodowego (Serviciul de Cercetare Metodologie),

- Oddział Konserwacji Kolekcji (Serviciul Conservarea Colecţiilor),

- Oddział Magazynowania i Ochrony Zbiorów - współpracuje ściśle z Oddziałem Informacji i Public Relations,

- Oddział Komunikacji Kolekcji (oddział udostępniania) (Serviciul Comunicarea Colecțiilor),

- Oddział Restaurowania i Ochrony Książek (Serviciul restaurare şi Prezervarea Publicaţiilor),

- Oddział Informacji i Public Relations (Biroul de Informaţii şi Relații Publice),

- Oddział Administracyjno-Gospodarczy (Biroul Administrativ - Tehnic).

Oświaty, które przewiduje budżet, zatwierdza zasady ich organizacji, funkcjonowania oraz ich schemat. Znajdują się one w dużych ośrodkach akademickich, w których jest kilka uniwersytetów. Te z kolei mają swoje biblioteki działające na zasadach samofinansowania. Biblioteki uniwersyteckie są finansowane przez uniwersytety z dużych ośrodków akademickich, ze środków własnych. 


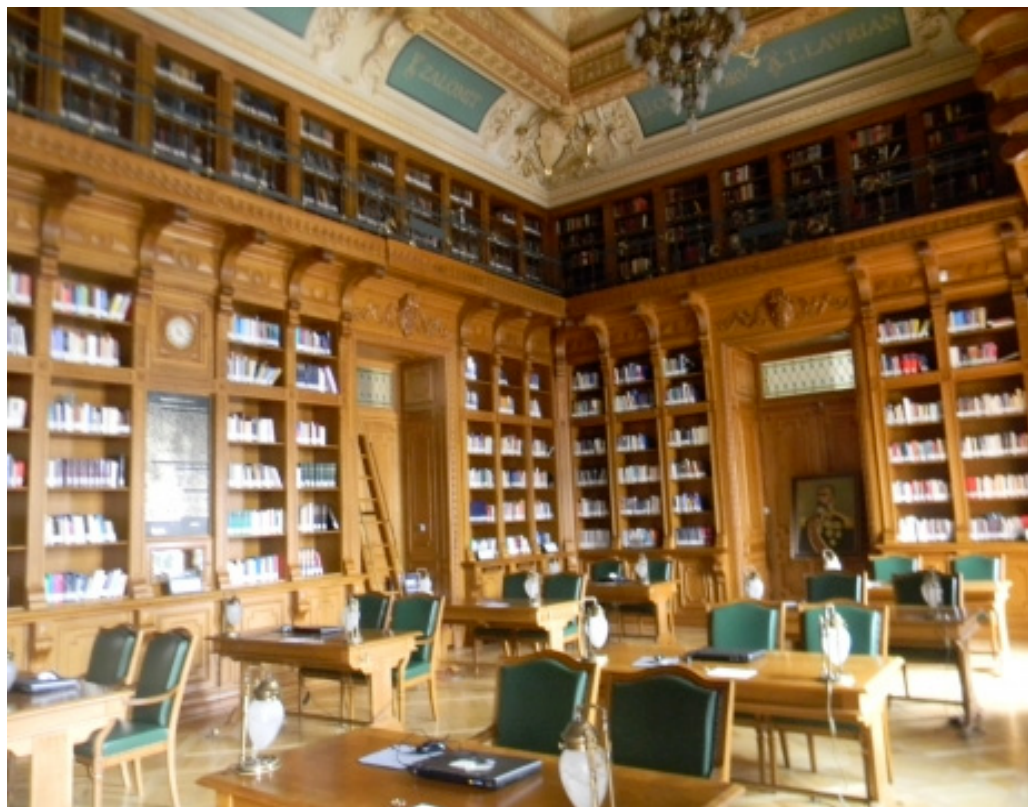

Il. 3. Czytelnia Profesorska Centralnej Biblioteki Uniwersyteckiej Fot. Iuliana Grażyńska.

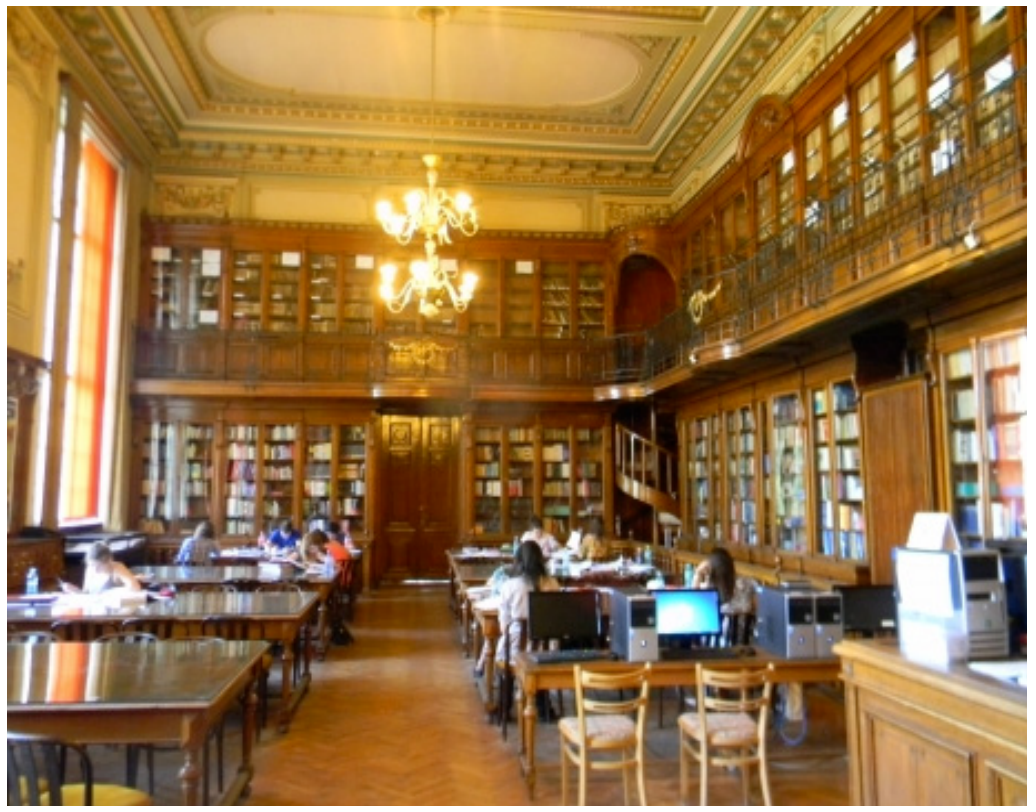

Il. 4. Sala Toma Ionescu

Fot. Iuliana Grażyńska. 


\section{Oddział Zbiorów Specjalnych Centralnej Biblioteki Uniwersyteckiej w Bukareszcie}

W Oddziale Zbiorów Specjalnych, który miałam przyjemność odwiedzić, jak w soczewce skupiły się historia i tradycja biblioteki. Od samego początku główną troską fundacji królewskiej było pozyskiwanie starych dokumentów o wartości bibliofilskiej, gromadzonych na zlecenie kadry uniwersyteckiej. Oprócz najstarszych wydań pisarzy antycznych, pamiętników, kronik i biografii związanych z historią średniowieczną i współczesną Włoch, Węgier, Niemiec, Rosji, Polski i Turcji w kolekcji bibliofilskiej pojawiły się dzieła hospodarów rumuńskich (np. Dimitrie Cantemira), a także te, które wcześniej stanowiły część ich bibliotek. Znalazły tu swoje miejsce pozostałości księgozbiorów o wartości historycznej, pochodzące z bibliotek władców (Constantina Brâncoveanu, Nicolae i Constantina Mavrocordata i innych), uczonych humanistów (Mirona Costina, Udrişte Nasturela, Constantina Cantacuzino), duchownych (Dosoftei, Antima Ivireanula) czy rodzin szlacheckich (Balsa, Rosetti, Brukenthal, Teleki). Włączono do kolekcji również niepublikowane rękopisy z zakresu teologii i literatury rumuńskiej. Większość z nich datowano na wiek XVIII.

Nadeszła jednak rewolucja i

po tym jak z biegiem czasu [zbiory - I.G.] stawiły czoło dwóm wojnom, dwóm trzęsieniom ziemi, nie mogły już przetrwać rewolucji z grudnia 1989 r., co spowodowało, że z imponujących kolekcji, które w danym momencie liczyły ponad 12000 woluminów, zostało ich tylko 10-12...4.

Prace w Oddziale Zbiorów Specjalnych skupiły się zatem na odnowieniu zniszczonej kolekcji i utworzeniu wysokiej jakości laboratorium patologii oraz odnowy książki. Szczegółowe opracowanie na ten temat przygotował dr Doru Badara, kierownik oddziału.

\section{Opracowanie zbiorów specjalnych}

Katalogowanie kolekcji rozpoczęło się w 1990 roku i wykonuje się je zgodnie z międzynarodowymi standardami w programie VUBIS, wykorzystując format UNIMARC. Językiem haseł przedmiotowych jest znany RAMEAU.

${ }^{4}$ Dokument online na stronie BCU, http://www.bcub.ro/cataloage/unibib/valoribibliofile-in-biblioteca-centrala-universitara-din-bucuresti [dostęp: 22.05.2010]. 
W czasie wizyty umożliwiono mi porównanie możliwości opisu bibliograficznego $\mathrm{w}$ formacie UNIMARC i MARC21. Wybrane przykłady pokazały różnice i podobieństwa między rumuńskim i polskim systemem bibliotecznym, wykorzystanie pól i podpól obu formatów. Do dziś dokumenty są przetwarzane w programie Vubism@rt. Po wieloletnim doświadczeniu sporządzono kompletny zestaw procedur opracowania dla każdego typu dokumentu. Do każdego opisu bibliograficznego dołącza się zdjęcie strony tytułowej oraz spis treści.

Na uwagę zasługuje stopień szczegółowości katalogowania książek w systemie i projekt digitalizacji zasobów (digitizare Restitutio).

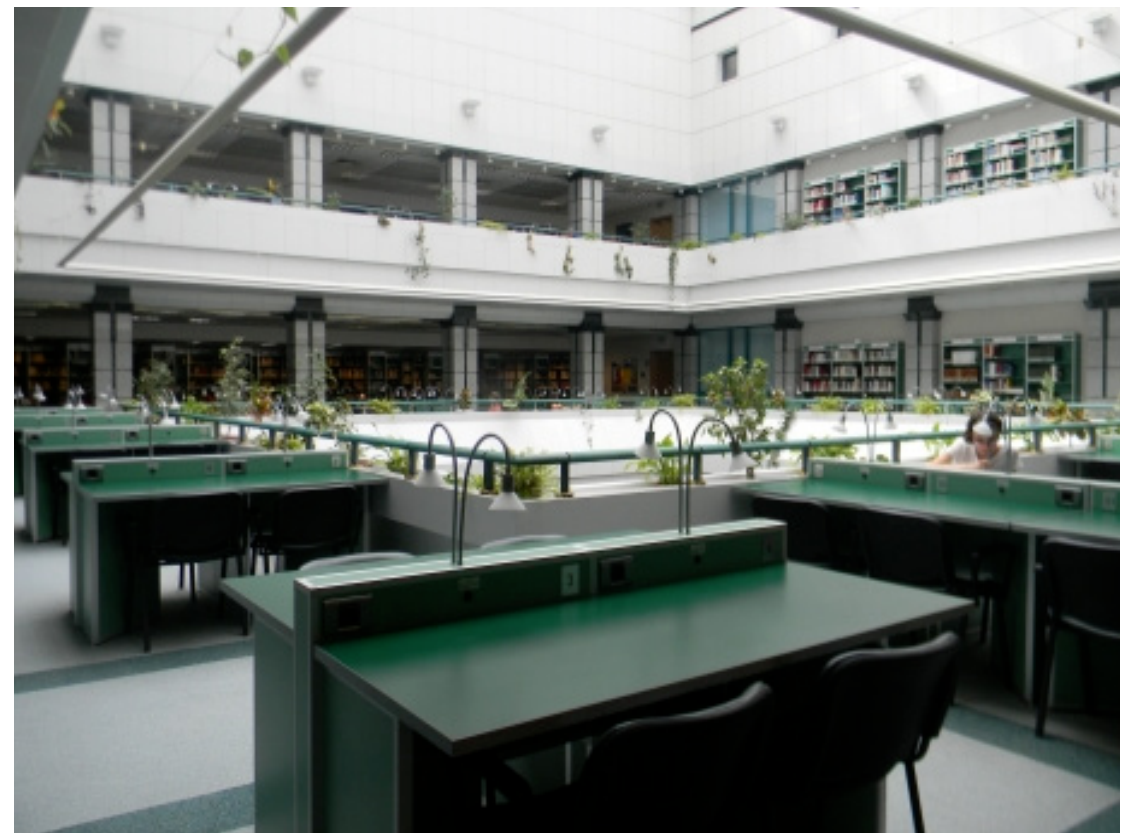

Il. 5. Sala Stefana O. Iosifa Fot. Iuliana Grażyńska.

\section{Działalność społeczna i kulturalna Centralnej Biblioteki Uniwersyteckiej}

Fundacją ciągle bardzo interesuje się rumuńska rodzina królewska, nie tylko dlatego, że jej początek dał założyciel dynastii, ale również dlatego, że widzi w niej ważną instytucję, która pielęgnuje i promuje narodowe wartości. 
Zgodnie z zamysłem króla Karola I w gmachu biblioteki odbywają się wydarzenia naukowe i polityczne o światowym znaczeniu, dzięki czemu bukareszteńska książnica lokuje się w pierwszej setce najważniejszych bibliotek świata. Amfiteatr biblioteki, mieszczący ponad 400 widzów, w okresie międzywojennym był miejscem szczególnym dla mieszkańców Bukaresztu. Można tu było uczestniczyć w konferencjach organizowanych przez ważne ośrodki życia naukowego i kulturalnego zarówno Rumunii, jak i świata. I dziś tradycja ta jest kontynuowana. W roku 2009 w Centralnej Bibliotece Uniwersyteckiej Karola I odbyły się m.in.: międzynarodowe seminarium "Zarządzanie jakością w europejskich bibliotekach uniwersyteckich” (23.02.2009), konferencja „Patriotyzm i dziedzictwo narodowe" (24.03.2009), konferencja „Dwa tysiąclecia kultury łacińskiej: historia, archeologia, architektura pomiędzy Włochami i Rumunią" (27.05.2009), seria konferencji „Rumunia - Francja: razem w Europie oraz Instytucje Europejskie na rozstaju dróg” (13.05.2009), konferencja „Ku nowym limitom w świecie poznania przez eksperymenty w LHC CERN Szwajcaria" (24.06.2009), sympozjum „20 lat od upadku Muru Berlińskiego”, zorganizowane 6.11.2009 roku z udziałem Komisji Europejskiej w Rumunii, konferencja wiceprezydenta Stanów Zjednoczonych Joe Bidena na temat ukierunkowania polityki wobec regionu, w którym jest usytuowana Rumunia (22.10.2009).

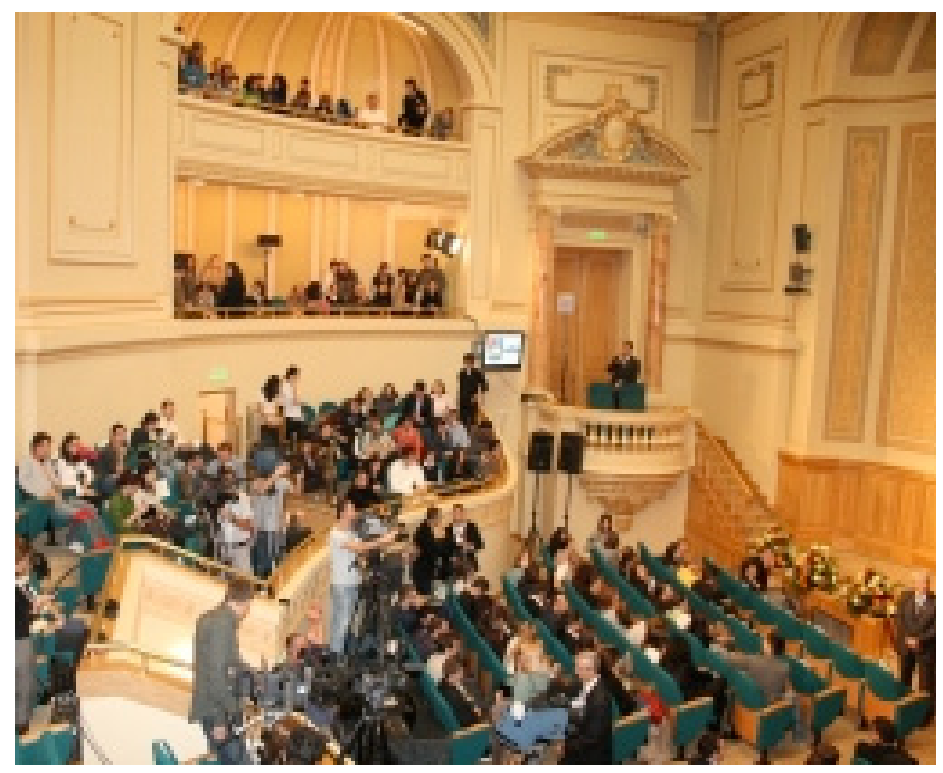

Il. 6. Aula Centralnej Biblioteki Uniwersyteckiej

Źródło: archiwum Centralnej Biblioteki Uniwersyteckiej Karola I w Bukareszcie. 


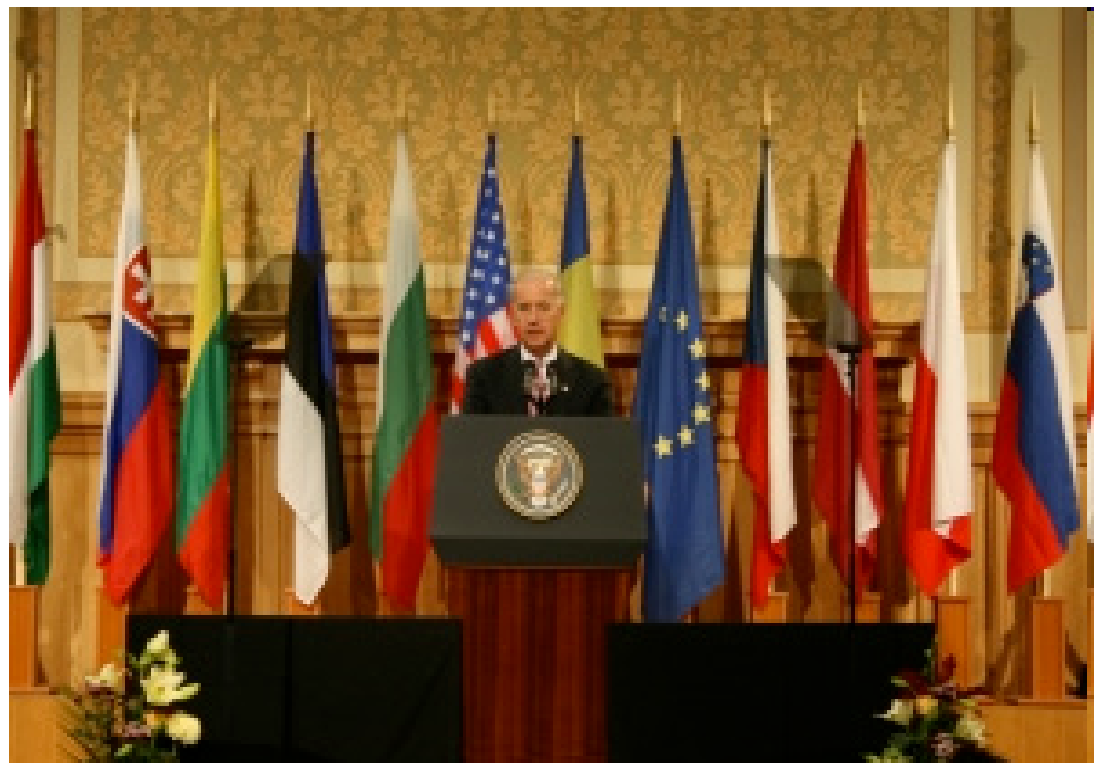

Il. 7. Aula Centralnej Biblioteki Uniwersyteckiej

Źródło: archiwum Centralnej Biblioteki Uniwersyteckiej Karola I w Bukareszcie.

\section{Realizacja zadań statutowych Centralnej Biblioteki Uniwersyteckiej Karola I w Bukareszcie}

W zinformatyzowanej społeczności szybki przepływ informacji stał się priorytetem. Kierownictwo biblioteki zmaga się z wieloma dylematami, ustalając optymalne relacje między organizowaniem, planowaniem, kontrolą i zarządzaniem, by dostosować usługi do oczekiwań odbiorcy.

Strona internetowa dla użytkowników oraz film prezentujący bibliote$\mathrm{kę}^{5}$ przedstawiają imponujący obraz placówki. Jej kolekcje zgromadzone w siedzibie głównej i w oddziałach liczą 2063103 tomy książek i 2415185 egzemplarzy czasopism. Biblioteka oferuje 385 miejsc do czytania i 52 stanowiska komputerowe. Czas opracowania nabytków od zakupu do ustawienia na półce to dwa dni. Realizacja zamówienia od chwili złożenia rewersu do chwili dostarczenia książki na biurko użytkownika trwa nie więcej niż 15 minut. W roku 2009 liczba zarejestrowanych czytelników wynosiła 27 659, a frekwencja sięgnęła 369964 odwiedzin. W ramach wymiany międzybibliotecznej Centralna Biblioteka Uniwersytecka w Bukareszcie współpracuje z 350 partnerami zagranicznymi.

${ }^{5}$ Zob. http://www.bcub.ro [dostęp: 22.10.2009]. 


\section{Infrastruktura informatyczna}

W roku 1994 Centralna Biblioteka Uniwersytecka w Bukareszcie jako pierwsza biblioteka w Rumunii wprowadziła komputerowy system informatyczny. Zintegrowany program VUBIS pozwolił na dostęp do kompleksowych usług: zarówno do własnych baz danych, jak i do narodowych czy międzynarodowych baz bibliograficznych. Proces komputeryzacji zaczął się w 1990 roku, od wprowadzenia w CDS-ISIS dokumentów.

Od roku 1996 Centralna Biblioteka Uniwersytecka oferuje swoim użytkownikom możliwość dostępu online do ponad 50 baz danych przez produkt First Search - On-line Computer Library Center ${ }^{6}$.

Biblioteka posiada 12 specjalistycznych czytelń (ze zbiorami z poszczególnych dziedzin).

Po szerokiej konsultacji w kraju i we Francji Rumunia implementowała system w centrach dokumentacyjnych na wszystkich szczeblach edukacji: szkolny i uniwersytecki (preuniversitar si universitar) według wewnętrznych potrzeb. W Bibliotece Uniwersyteckiej znajduje się Centrum Dokumentacji Europejskiej im. Roberta Schumana, z dostępem do najnowszych informacji na temat Unii Europejskiej. Jednostka ta jest częścią krajowej sieci Europejskich Centrów Dokumentacji (European Documentation Centres), pod bezpośrednim nadzorem Przedstawicielstwa Komisji Europejskiej w Rumunii. Dysponuje kolekcją dokumentów na tematy europejskie i wysokiej jakości sprzętem do gromadzenia i udostępniania lokalnych i internetowych zasobów elektronicznych. Do jej zadań należy dostarczanie kompleksowych informacji na temat legislacji unijnych, polityki i debat europejskich. Wiadomości te są dostępne w katalogu OPAC biblioteki, na serwerze EUROPA oraz w bibliograficznych bazach danych EUREF.

Centralna Biblioteka Uniwersytecka aktywnie uczestniczy w projekcie „Partnerstwo Info Europa”. Projektem rozwijanym w ramach programu PHARE EUROPA i finansowanym przez Unię Europejską administruje Delegacja Komisji Europejskiej w Rumunii (http://www.euref.ro).

Kilka dni spędzonych w Centralnej Bibliotece Uniwersyteckiej w Bukareszcie pozwoliło mi poznać różnice i podobieństwa między rumuńskim i polskim systemem bibliotecznym. Wróciłam do Poznania z nowym

${ }^{6}$ Ohio College Library Center i członkowskie biblioteki zapewniają aktualizacje największego katalogu online - WorldCat. 
doświadczeniem zawodowym. Szybki przyrost liczby projektów unijnych, rozwój usług oferowanych przez Centralną Bibliotekę Uniwersytecką oraz możliwość współpracy w różnych zakresach pozwalają żywić nadzieję, że moja wizyta w Bukareszcie nie będzie ostatnia.

W bukareszteńskiej bibliotece spotkałam się z serdeczną gościnnością. Ze szczególną wdzięcznością wspominam Panią Dyrektor Voichitę Drogomir - za rzeczową współpracę - oraz Panie Cristinę Badara i Andreę Tudor, które zapoznały mnie z tamtejszym sposobem opracowania starych druków. Specjalne podziękowania należą się Panu Drowi Doru Badara, szefowi Oddziału Zbiorów Specjalnych, wybitnemu znawcy starych książek i laureatowi Akademii Rumuńskiej w 1998 roku za pracę Druk rumuński pod koniec XVII i na początku XVIII wieku. Dr Badara z wyjątkową uprzejmością i profesjonalizmem opowiedział o historii biblioteki oraz towarzysząc mi codziennie - zapoznał z pracą poszczególnych działów.

\title{
Bibliografia
}

Biblioteca Centrala Universitară din Bucureşti. O bibliografie a existenței 1891-2001 (Biblioteka Główna Uniwersytecka w Bukareszcie. Bibliografia za lata 1891-2001), Bukareszt, BCU, 2001.

Costescu G., Bucureştii vechiului regat (Bukareszt królestwa rumuńskiego), Bukareszt 2005.

Costin M., Latopis Ziemi Mołdawskiej i inne utwory historyczne, przeł. I. Czamańska, Poznań 1998.

Biblioteca Centrala Universitara "Carol I" [dokumenty online na stronie BCU, http:// www.bcub.ro oraz http://www.bcub.ro/cataloage/unibib/valori-bibliofile-inbiblioteca-centrala-universitara-din-bucuresti [dostęp: 22.05.2010].

\author{
IULIANA GRAŻYŃSKA
}

\section{The Central University Library of the Carol I National Defence University in Bucharest}

\footnotetext{
Aвstract. The article summarises experiences gained through the author's practice as a trainee during a placement internship organized within the framework of the Erasmus programme at the library of the Carol I National Defence University (Romanian: Universitatea Națională de Apărare "Carol I") in Bucharest. Differences and similarities between Polish and Romanian library systems are discussed as well as the methods for book processing in the Special Collections Division of the library,
} 
other library services and the tumultuous history of the library. Bucharest University Library was the first Romanian library to introduce a fully automated integrated information system. Book processing is carried out in the VUBIS bibliographic record program based on the UNIMARC format. The cooperation of the library with 350 foreign partners allow its users to have access to the most recent research results and advanced research services.

Key words: Erasmus programme, Romania, Central Library of the Carol I National Defence University in Bucharest, cataloguing of special collections. 